\title{
The Research of the Mineralogical and Element Geochemical Characteris- tics of Bauxite in Yunfeng, Qingzhen, in Central Guizhou Province, China
}

\author{
Yang $\mathrm{Wu}^{*}$, Dai Tagen and Long Yongzhen \\ School of Geosciences and Info-Physics, Central South University, Hunan Changsha, 410083, P.R. China
}

\begin{abstract}
The mineralogical and geochemical characteristics of the Yunfeng bauxite in Qingzhen were investigated through the handle specimen observation, thin section analysis, XRD、SEM and Element geochemistry. The mineral analyses reveal that diaspore, kaolinite and chlorite are the major minerals in the bauxite with small amounts of boehmite and pyrite. Geochemical investigations reveal that the main components in the bauxite are $\mathrm{Al}_{2} \mathrm{O}_{3}, \mathrm{SiO}_{2}$ and $\mathrm{TFe}_{2} \mathrm{O}_{3}$, the minorcomponents are $\mathrm{TiO}_{2}, \mathrm{MgO}$ and $\mathrm{P}_{2} \mathrm{O}_{5}$. In the process of weathering, some trace elements, such as $\mathrm{Zr}, \mathrm{Cr}, \mathrm{Nb}$ and $\mathrm{Hf}$, are enriched. $\mathrm{Zr}$ vs $\mathrm{Hf}$ and $\mathrm{Nb}$ vs Ta display higher positive correlation. Trace elements show that Loushanguan Formation is the main source of material for the bauxite formation and there may be exist other precursor rock provide few material for the bauxite formation. Ore deposit formed in a O-poor,reducing Marine sedimentary environment.
\end{abstract}

Keywords: Major elements, trace elements, parent rock, bauxite, metallogenetic environment.

\section{INTRODUCTION}

As the second largest bauxite resource base in China, Guizhou Province has a rich bauxite resources, reserves and basic reserves in 155.23 and 216.25 milliontons by the end of 2008 [1]. Its distribution is wide: from Guiyang Qingzhen and Wuchuan-Zheng'an-Daozhen area. It Formed a north north east direction bauxite metallogenic belt. a lot of research about Guizhou bauxite have been done, the study of the ore deposits and sedimentology are discussed in detail. LiuPing [2-3] found the evolution of bauxite in north-central Guizhou province can be divided into three steps; laterization from late late devonian epoch to early early carboniferous epoch; transported deposit in Late carboniferous epoch and the later diagenesis and supergene action. Liu Xunfeng [4] based on the study of profile structure of ore deposit and parent rock composition, found that in early carboniferous epoch, phase of desilicication and reducing iron in laterization process creates good conditions for bauxite form. Chen [5] pointed out that the acidic condition is conducive to silicon and aluminum fractionation because humic acid can enhance the ability of $\mathrm{SiO}_{2} \mathrm{Fe}_{2} \mathrm{O}_{3}$ and $\mathrm{Al}_{2} \mathrm{O}_{3}$ migration. But previous research on mineralogy and geochemistry characteristics of bauxite is still relatively lack.

In this paper, the author through field geological survey, thin section microscopic identification, XRD, scanning electron microscopy (SEM) and element geochemical analysis of the bauxite in Qingzhen district, Guizhou Province, To discuss Bauxite metallogenic environment and ore-forming process and make a comprehensive analysis of bauxite source.

*Address correspondence to this author at the School of Geosciences and Info-Physics, Central South University, Hunan Changsha, 410083, P.R. China; E-mail: 774762582@qq.com

\section{REGIONAL GEOLOGICAL CHARACTERISTICS}

QingZhen is located in the middle of GuiZhou Province, contains rich bauxite resources and convenient transportation. The Regional tectonic position is in Yangtze paraplatform Guiyang complex tectonic deformation zone. After a long period of weathering denudation in central Guizhou, In the late devonian period it formed a expectant lysogenic landscape, constituting a favorable basis of geological conditions for mineralization. In early carboniferous epoch DaTang stage, the south China sea invasion from the south to north. Qingzhen region belongs to karst depressions and shallow lake fades. The sedimentary formation of carboniferous is JiuJiaLu group containing Al-bearing rock series. The transgressive in Permian is expanded. To Qixia stage, it is completely into carbonate deposition [6].

The stratums of Mining area and the surrounding are composed of the middle Cambrian Lengshui formation $(\in$ $\left.{ }_{2} \mathrm{~S}\right)$, middle-upper Cambrian Loushanguan group $\left(\in_{2-3} 1 \mathrm{~s}\right)$, the lower carboniferous Jiujialu group $\left(\mathrm{C}_{1} \mathrm{jj}\right)$, the middle Permian Liangshan group $(\mathrm{Pl})$, Qixia group $\left(\mathrm{P}_{2} \mathrm{q}\right)$, Maokou group $\left(\mathrm{P}_{2} \mathrm{~m}\right)$ and Quaternary System $(\mathrm{Q})$.

Deposits occur in the carboniferous Jiujialu Formation, The contact relationship between the upper and lower strata is parallel unconformity.

Ore bodies are bedded, occur in the Lower carboniferous Jiujialu Formation. Tendency is from $126^{\circ}$ to $150^{\circ}$ with dip angle of $20^{\circ}$. The Ore bodies occur along dipping direction is about $400 \mathrm{~m}$ and their lengths in this direction is more than $600 \mathrm{~m}$. The thickness of Ore body vary from $1.09 \mathrm{~m}$ to $4.57 \mathrm{~m}$ and the $\mathrm{Al} 2 \mathrm{O} 3$ content is from $59.75 \mathrm{wt} \%$ to $71.01 \mathrm{wt} \%, \mathrm{Al} / \mathrm{Si}$ is from 11.07 to 13.33, with an average of 11.98 (Fig. 1). 


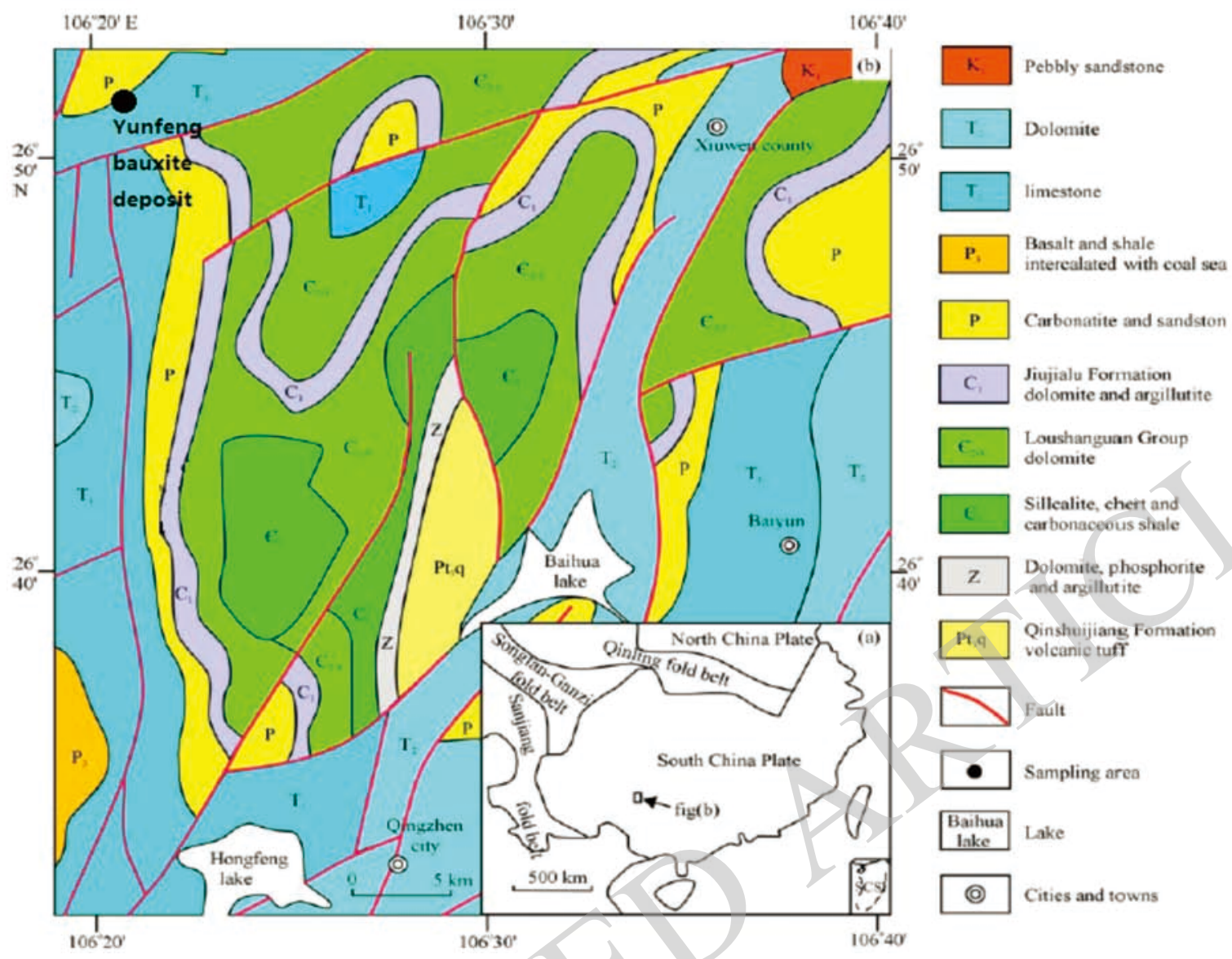

Fig. (1). (a), an index map of South China Plate showing the location of theYunFeng bauxite deposit; (b), Geologic map illustrating the geological features of the Lindai bauxite deposit, Guiyang, China. (Ling Kunyue et al., 2013).

\section{SAMPLING AND TESTING METHODS}

All samples is tunnel sampling. throughout the mining area, different ore block, ore types, and typical ore block is sampled and We choose 39 samples to test and analysis. Xray diffractometry and scanning electron microscopy were done in the institute of mining and metallurgy(Changsha). The instrument is Bruker -D8; Test condition: choose copper target, $40 \mathrm{kV}, 40 \mathrm{~mA}$. Major and trace element analysis was carried out at the ALS mineral laboratory, China. Major oxides contents were measured by X-Ray Fluorescence(XRF) technique, and trace element were analyzed by the inductively coupled plasma mass spectrometry (ICP-MS) techniques.

\section{CHARACTERISTICS OF MINERALOGY AND MINERAL STRUCTURE}

\subsection{Mineralogy Characteristics}

The microscopic identification of XRD, SEM and probe showed that the bauxite ore is mainly composed of diaspore, boehmite, kaolinite, and we also found some mica, anatase, rutile, oolite chlorite, quartz, gypsum, etc. Diaspore is the major aluminum and ore minerals. it is grey, light yellow in microscope, the crystal shape is micro crystal, electron probe shows it is lamellar, acicular, columnar which is generally less than 5 microns (Fig. 2). Kaoliniteis pale gray, tiny particles, the microscope show it is fragmental or as a nuclear in the center of the oolitic.Mica has sericitization with residual metasomatic texture structure.

\subsection{Ore Structure Characteristics}

The textures of ores are common in Soil structure, massive structure, clastic structure and oolitic structure. Dense bauxite ore is smooth, hard and dense. Earthy bauxite ore is loose, coarse and relatively light. Clastic structure is common, but poorly sorted (Fig. 3).

\section{GEOCHEMICAL CHARACTERISTICS}

Element geochemistry is widely used and develop rapidly. Initially, the element geochemical method is mainly used in research for igneous rock, then the application element geochemical means identifying expanded into sedimentary rock. To analysis the sedimentary environment, sediment provenance and depositional background has been widely applied. 

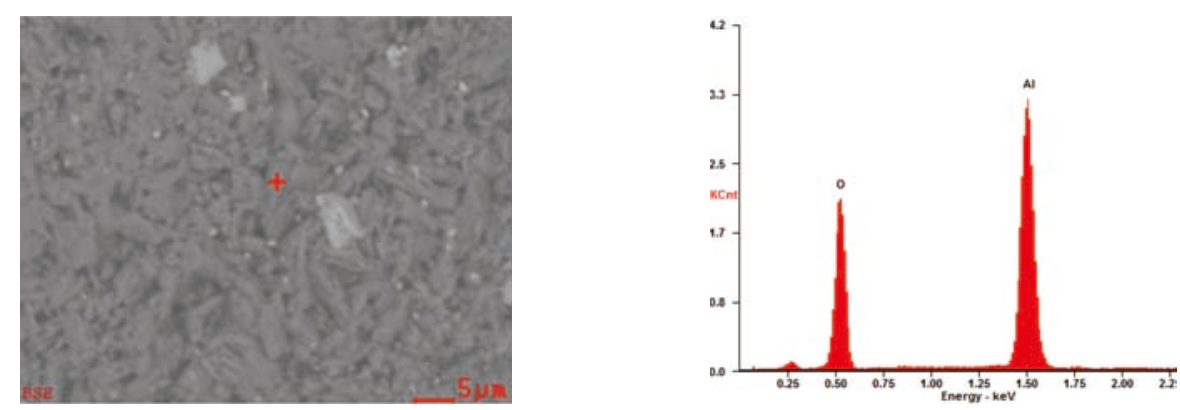

(a) Diaspore
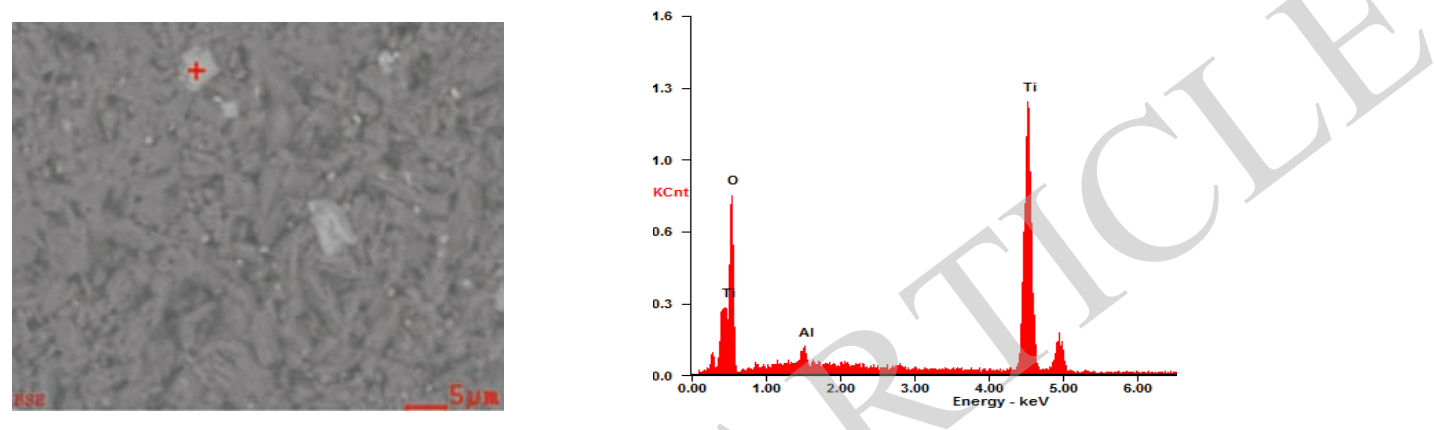

(b) Anatase

Fig. (2). SEM images of mineral and corresponding EDX spectra.
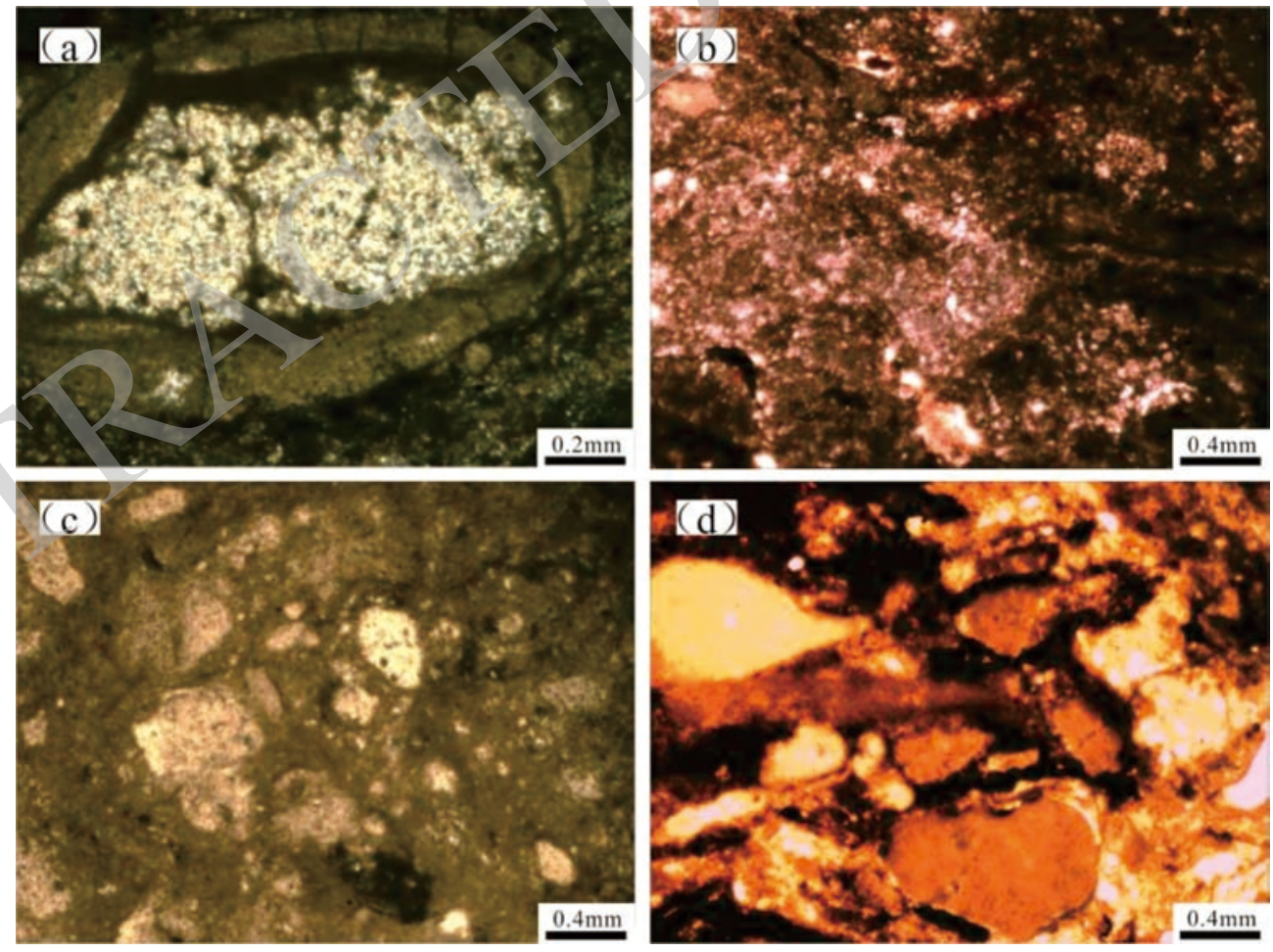

(a) sericitization in the center of oolite (white) (b) earthy ore

(c) clastic structure (d) debris, irregular form(Iron-rich)

Fig. (3). Structure characteristics of bauxite in Yunfeng. 

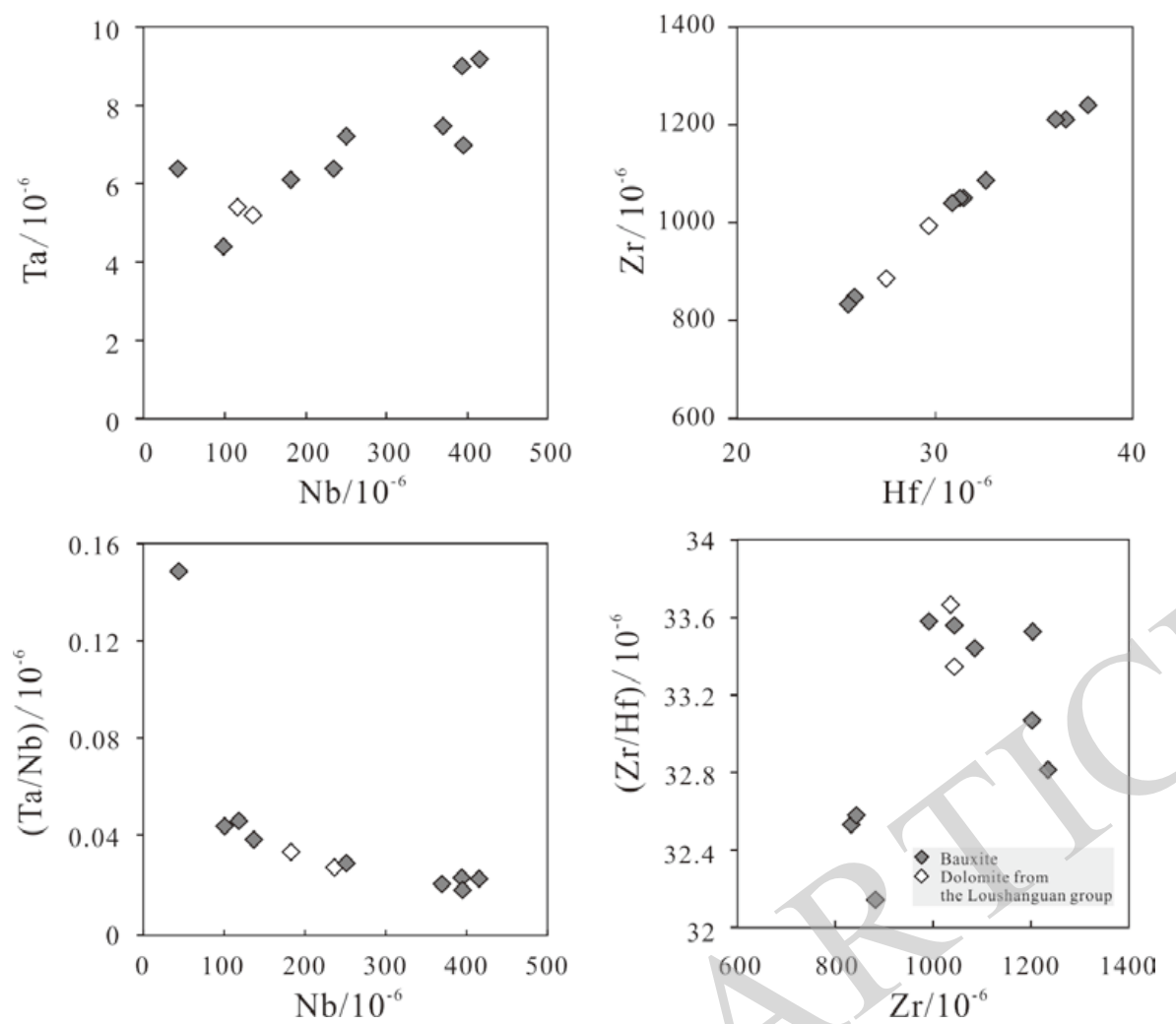

Fig. (4). Binary diagrams showing correlation between $\mathrm{TiO}_{2}$ and stable trace elements.

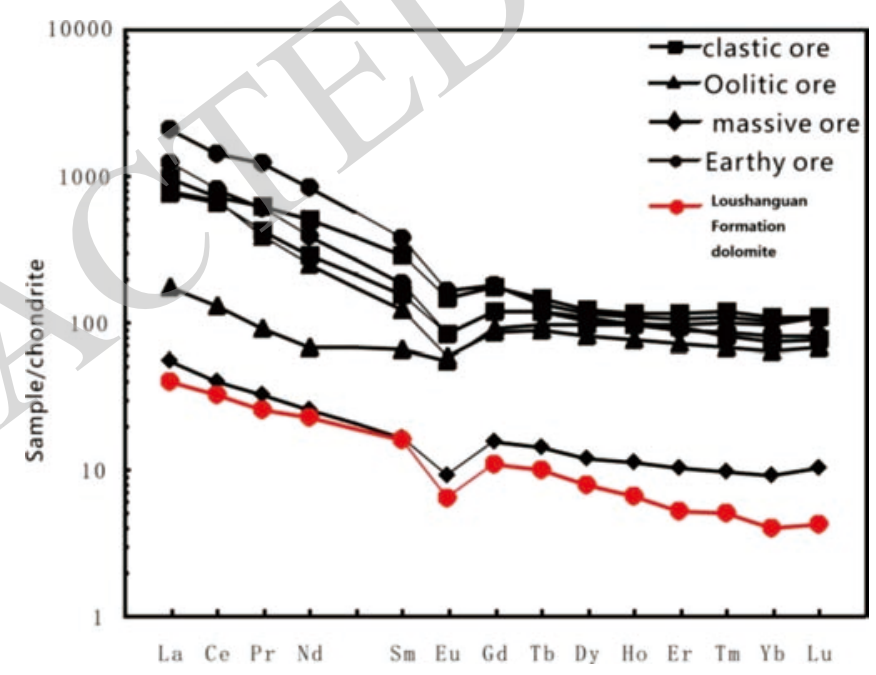

Fig. (5). Normalized diagrams showing REE distributionpatterns of all bauxite and Loushanguan Formation.

\subsection{Major Element Characteristics}

The Major elements in bauxite ore are $\mathrm{Al}_{2} \mathrm{O}_{3}(56.75 \% \sim 73.66), \quad \mathrm{SiO}_{2}(1.56 \% \sim 11.99 \%), \quad \mathrm{Fe}_{2} \mathrm{O}_{3}$ (1.11\% 3.0\%), $\mathrm{TiO}_{2}(2.32 \% \sim 4.34 \%)$ and the range of those elements distribution is wide (Fig. 4). Alkaline elements content is lower and the change range is smaller, $\mathrm{K}(0.08 \%$ $3.67 \%), \mathrm{Na}(0.04 \% \sim 0.3 \%)$. $\mathrm{Al}_{2} \mathrm{O}_{3}$ has a positively correlated with $\mathrm{TiO}_{2}$, but negatively correlated with $\mathrm{SiO}_{2}$ and $\mathrm{Fe}_{2} \mathrm{O}_{3}$.

\subsection{Trace Element Characteristics}

Compared with abundance of chemical elements in the continental crust by Taylor (1985), Parts of the trace elements in Yunfeng bauxite is enrichment (Fig. 5). The content of $\mathrm{Zr}$ can be $4.13 \times 10^{-3} \mathrm{ppm}, \mathrm{Cr}$ is above $1.2 \times 10^{-4} \mathrm{ppm}, \quad \mathrm{V}$ is $1.36 \sim 2.97 \times 10^{-4} \mathrm{ppm}$. Sr content in most samples is above 5 $\times 10^{-6} \mathrm{ppm}$ (Table 1). $\mathrm{Zr}$ content is in the range of $8.26 \times 10^{-4} \sim 1.24 \times 10^{-3} \mathrm{ppm}$, an average of $1 \times 10^{-3} \mathrm{ppm}$, with 

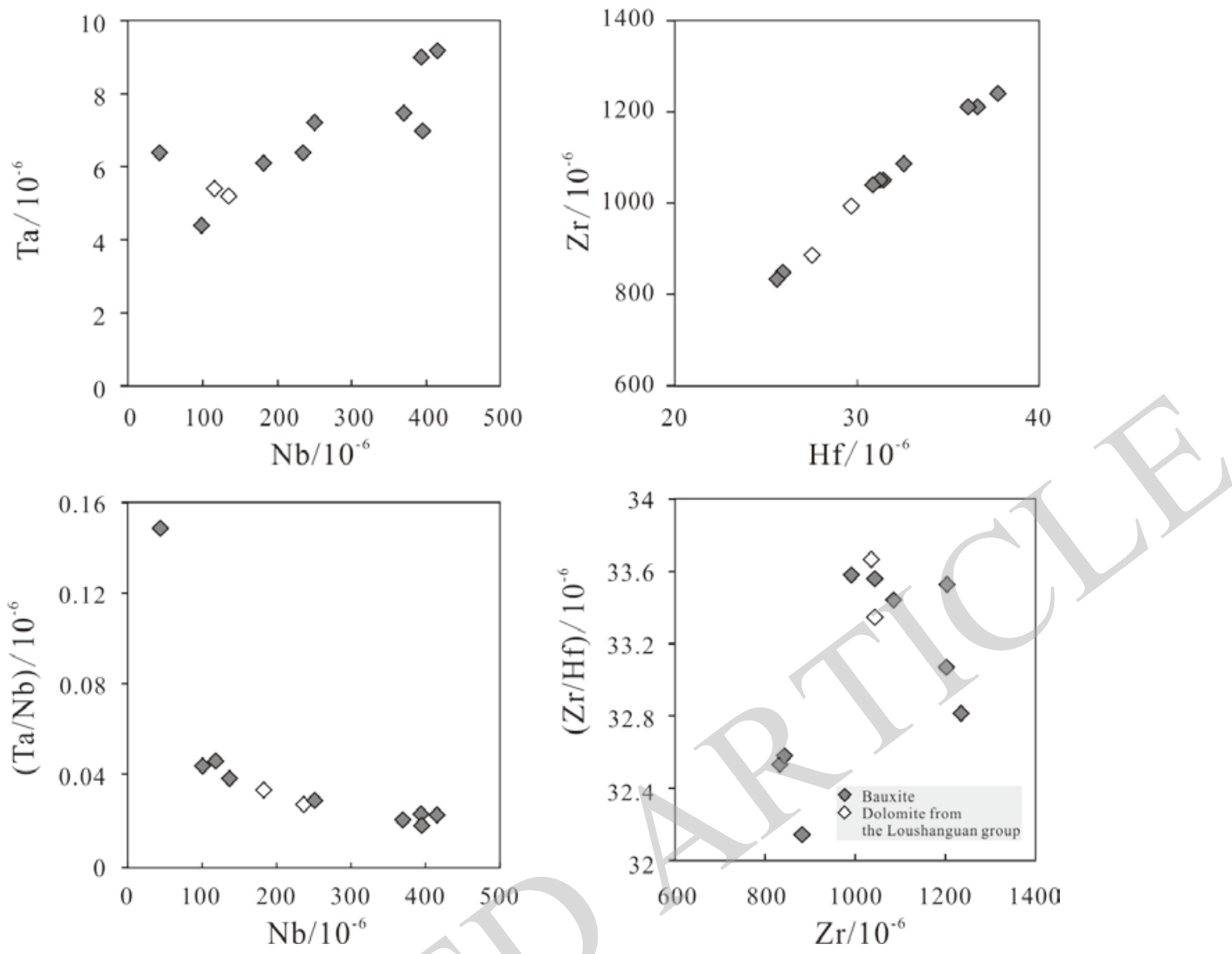

Fig. (6). Plot diagrams of trace elements $\mathrm{Nb}, \mathrm{Ta}, \mathrm{Zr}$ and $\mathrm{Hf}$.

obvious positive anomaly. Hf content is relatively stable, from $2.57 \times 10^{-5} \sim 3.78 \times 10^{-5}$, an average of $3.04 \times 10^{-5} ; \mathrm{Nb}$ content is from5.6 $6 \times 10^{-5} \sim 1.8 \times 10^{-4} \mathrm{ppm}$. Compared with stratigraphic clark value, $\mathrm{Zr}$ and $\mathrm{Hf}$ have higher concentration ratio, for six times and 10 times respectively, $\mathrm{Nb}$ has 4.3 times; $\mathrm{V}$ and $\mathrm{Cr}$ concentration ratio is low, only 1.7 times. $\mathrm{Ti}$ can be preserved on the surface by accessory mineral rutile (detrital minerals) or in the form of new mineral:anatase . it is relatively stable, and can be an ideal reference element to study the surface element geochemical behavior [7]. Zr, Hf, $\mathrm{Nb}$ and $\mathrm{Ta}$ have a good linear correlation with $\mathrm{TiO}_{2}$, it shows $\mathrm{Zr}, \mathrm{Hf}, \mathrm{Nb}$ and $\mathrm{Ta}$ has remained relatively stable state in the process of bauxite mineralization.

\subsection{The Rare Earth Element(REE) Characteristics}

The standard curve of chondrite of rare earth element reveals a enrichment of LREE and HREE is relatively flat, it show a weak Ce anomaly (Fig. 6). The $\sum$ REE contents in four different types of bauxite vary varied widely

Rare earth element (REE) contents of earthy bauxite range from 11.51 to $20.46 \times 10^{-4} \mathrm{ppm}$, indicating significant fractionation between light REE (LREE) and heavy REE (HREE) with LREE/HREE ratios of $16.34,(\mathrm{La} / \mathrm{Sm})_{\mathrm{N}}$ is 8.52 , $(\mathrm{Gd} / \mathrm{Yb})_{\mathrm{N}}$ is 2.06 and $(\mathrm{La} / \mathrm{Yb})_{\mathrm{N}}$ is 20.02 . The polyline patterns have a distinct negative $\mathrm{Eu}$ anomaly, a positive $\mathrm{Ce}$ anomaly, and are enriched in LREE.
Rare earth element contents of clastic bauxite range from 8.85 to $11.42 \times 10^{-4} \mathrm{ppm}, \mathrm{s}$ LREE/HREE values 8.49 , $(\mathrm{La} / \mathrm{Sm})_{\mathrm{N}}$ ratios of $7.66,(\mathrm{Gd} / \mathrm{Yb})_{\mathrm{N}}$ ratios of 1.94 and $(\mathrm{La} / \mathrm{Yb})_{\mathrm{N}}$ ratios of 10.21 , due to LREE enrichment. The polyline patterns have a negative Eu anomaly and slight positive Ce anomaly.

Rare earth element contents of oolitic bauxite vary from 2.66 to $8.45 \times 10^{-4} \mathrm{ppm}$, showing significant fraction between LREE and HREE with LREE/HREE ratios of 10.6, $(\mathrm{La} / \mathrm{Sm})_{\mathrm{N}}$ ratios of $9.88,(\mathrm{Gd} / \mathrm{Yb})_{\mathrm{N}}$ ratios of 1.62 and $(\mathrm{La} / \mathrm{Yb})_{\mathrm{N}}$ ratios of 12.07 . The polyline patterns have a marked negative Eu anomaly.

The average total rare earth element contents of massive bauxite are $67 \times 10^{-6} \mathrm{ppm}$ showing less significant fraction between LREE and HREE with LREE/HREE ratios of 5.03, $(\mathrm{La} / \mathrm{Sm})_{\mathrm{N}}$ ratios of $5.24,(\mathrm{Gd} / \mathrm{Yb})_{\mathrm{N}}$ ratios of 2.05 and $(\mathrm{La} / \mathrm{Yb})_{\mathrm{N}}$ ratios of 6.07 . The polyline patterns have a marked negative Eu anomaly and a slight negative Ce anomaly.

Although leaching process changes REE patterns of bauxite host rock to some extent, The analyses above indicate that the same source of rock that bauxites and laterites share might be the underlying Loushanguan Formation dolomite. And the weathering laterite is the in-process products from mother rock to the bauxite. 
Table 1. REE data for bauxite: Yunfeng.

\begin{tabular}{|c|c|c|c|c|c|c|c|c|c|c|c|c|c|c|c|c|c|c|c|c|c|c|c|}
\hline \multirow{2}{*}{ Sample } & \multirow{2}{*}{ Name } & \multicolumn{18}{|c|}{$\mathrm{w} / \%$} & \multirow[b]{2}{*}{$\mathbf{S r} / \mathbf{B a}$} & \multirow[b]{2}{*}{$\mathbf{T h} / \mathbf{U}$} & \multirow[b]{2}{*}{$\mathrm{V} / \mathrm{Cr}$} & \multirow[b]{2}{*}{$\mathbf{C e}_{\text {anom }}$} \\
\hline & & $\mathrm{La}$ & $\mathrm{Ce}$ & $\mathrm{Pr}$ & Nd & Sm & Eu & Gd & $\mathbf{T b}$ & Dy & Ho & Er & $\mathbf{T m}$ & $\mathbf{Y b}$ & Lu & ¿REE & LREE & HREE & LREE/HREE & & & & \\
\hline Ksd-1 & clastic ore & 181.5 & 406 & 40.1 & 135.5 & 23.7 & 4.89 & 24.7 & 4.41 & 26.2 & 5.63 & 15.45 & 2.1 & 12.75 & 1.96 & 884.89 & 791.69 & 93.2 & 8.49 & 4.99 & 2.88 & 1.19 & 0.11 \\
\hline Ksd-2 & earthy ore & 494 & 858 & 115.5 & 393 & 58 & 9.55 & 36.6 & 5.09 & 29.5 & 6.19 & 17.5 & 2.76 & 17.7 & 2.81 & 2046.2 & 1928.05 & 118.15 & 16.32 & 25.13 & 2.88 & 1.22 & 0.03 \\
\hline Ksd-3 & Oolitic ore & 186 & 410 & 37.1 & 117 & 18.85 & 3.36 & 17.85 & 3.34 & 20.7 & 4.34 & 12.1 & 1.75 & 11.05 & 1.71 & 845.15 & 772.31 & 72.84 & 10.6 & 2.71 & 1.52 & 0.95 & 0.11 \\
\hline ksd-4 & clastic ore & 89.5 & 168 & 17.8 & 55.3 & 9.18 & 1.62 & 10.7 & 2.15 & 14.25 & 3.06 & 8.58 & 1.33 & 8.35 & 1.32 & 391.14 & 341.4 & 49.74 & 6.86 & 0.74 & 2.23 & 1.13 & -0.01 \\
\hline Ksd-6 & Ore (iron-rich) & 361 & 719 & 98.4 & 394 & 105.5 & 19.65 & 91.7 & 15.75 & 91.2 & 18.05 & 48.5 & 7.08 & 42.1 & 6.15 & 2018.08 & 1697.55 & 320.53 & 5.3 & 8.51 & 3.29 & 1.86 & 0.07 \\
\hline $\mathrm{JJI}-2$ & Ore body & 572 & 960 & 118.5 & 369 & 62.1 & 8.75 & 31.5 & 4.12 & 23.7 & 4.83 & 14.1 & 2.23 & 14.9 & 2.4 & 2188.13 & 2090.35 & 97.78 & 21.38 & 7.14 & 3.31 & 1.79 & 0.09 \\
\hline $92501-2$ & dense massive ore & 13.2 & 24.3 & 3.12 & 12.2 & 2.52 & 0.54 & 3.2 & 0.53 & 3 & 0.63 & 1.69 & 0.25 & 1.56 & 0.26 & 67 & 55.88 & 11.12 & 5.03 & 30.21 & 2.86 & 1.77 & 0.04 \\
\hline 92502 & clastic ore & 231 & 442 & 58.7 & 235 & 44.8 & 8.49 & 36.3 & 5.48 & 31.4 & 6.55 & 18.9 & 3 & 18.35 & 2.77 & 1142.74 & 1019.99 & 122.75 & 8.31 & 0.61 & 2.42 & 1.50 & 0.00 \\
\hline 92503 & bauxite & 57.6 & 101.5 & 12.2 & 42.9 & 8.16 & 1.67 & 9.2 & 1.92 & 13.5 & 3.07 & 8.88 & 1.37 & 9.2 & 1.44 & 272.61 & 224.03 & 48.58 & 4.61 & 11.82 & 3.25 & 1.44 & 0.05 \\
\hline 92504 & earthy ore & 286 & 498 & 56.7 & 182.5 & 28.6 & 4.86 & 24.7 & 4.47 & 27.4 & 5.47 & 14.8 & 2.19 & 13.75 & 2.06 & 1151.5 & 1056.66 & 94.84 & 11.14 & 1.68 & 2.05 & 0.63 & -0.17 \\
\hline 92506 & bauxite & 182 & 399 & 56.8 & 242 & 40.6 & 7.32 & 24.9 & $2.89^{\prime}$ & 15.45 & 3.01 & 8.69 & 1.34 & 8.67 & 1.39 & 994.06 & 927.72 & 66.34 & 13.98 & 22.45 & 2.62 & 0.71 & 0.03 \\
\hline 92510 & Oolitic ore & 41.6 & 80.2 & 8.61 & 32.2 & 10.1 & 3.26 & 18.95 & 3.62 & 24.5 & 5.44 & 15.95 & 2.57 & 16.45 & 2.81 & 266.26 & 175.97 & 90.29 & 1.95 & 3.85 & 3.30 & 1.13 & 0.13 \\
\hline 92513 & bauxite & 86.5 & 265 & 17.65 & 55 & 9.2 & 1.82 & 8.67 & 1.63 & 10.35 & 2.26 & 6.71 & 1.04 & 7.12 & 1.13 & 474.08 & 435.17 & 38.91 & 11.18 & 1.08 & 1.95 & 0.99 & -0.28 \\
\hline 92515 & bauxite & 96.2 & 232 & 21 & 62.5 & 10 & 1.85 & 8.18 & 1.4 & 9.56 & 2.23 & 6.75 & 1.09 & 7.48 & 1.18 & 461.42 & 423.55 & 37.87 & 11.18 & 34.50 & 2.65 & 0.91 & 0.19 \\
\hline 92519 & Oolitic ore & 517 & 833 & 120.5 & 415 & 70.1 & 12.65 & 47.9 & 6.51 & 36.6 & 7.34 & 20.6 & 3.18 & 19.7 & 3.15 & 2113.23 & 1968.25 & 144.98 & 13.58 & 23.69 & 2.10 & 1.16 & 0.12 \\
\hline 92526 & bauxite & 155 & 285 & 44.2 & 210 & 63.3 & 12.9 & 61.1 & 9.81 & 55.5 & 10.8 & 27.8 & 3.89 & 23.5 & 3.61 & 966.41 & 770.4 & 196.01 & 3.93 & 27.26 & 3.06 & 0.43 & 0.00 \\
\hline 92528 & bauxite & 304 & 530 & 70.6 & 251 & 45.9 & 7.88 & 33.6 & 5.17 & 30.6 & 6.28 & 17.3 & 2.69 & 16.95 & 2.66 & 1324.63 & 1209.38 & 115.25 & 10.49 & 8.71 & 3.29 & 3.03 & 0.05 \\
\hline 92529-2 & kaolinite & 229 & 373 & 60.6 & 232 & 28.8 & 4.54 & 17.6 & 2.34 & 13.35 & 2.76 & 8.43 & 1.45 & 10.2 & 1.68 & 985.75 & 927.94 & 57.81 & 16.05 & 9.79 & 2.96 & 2.06 & 0.02 \\
\hline Report & $\begin{array}{l}\text { dolomite } \\
\text { (Loushanguan } \\
\text { group) }\end{array}$ & 9.6 & & 2.47 & 10.55 & 2.47 & 0.37 & 2.25 & 0.38 & 1.99 & 0.38 & 0.88 & 0.13 & 0.68 & 0.11 & 51.98 & 45.18 & 6.8 & 6.64 & 34.00 & 3.16 & 1.64 & -0.01 \\
\hline
\end{tabular}




\section{ANALYSIS}

\subsection{The Formation of Minerals}

As a dominant mineral in bauxite deposit, diaspore may be formed in metamorphic or supergene conditions [8]. Metamorphic wall rock and corundum are common with formation of metamorphic diaspora [9], however, the wall rock of Yunfeng bauxite deposit mark rarely metamorphic feature and corundum do not appear. Hence, most diaspore in Yunfeng bauxite deposit is sedimentary origin. Both pyrite and kaolinite are common mineral in bauxite deposit. It is generally believed that sulfur within seawater in transgression and incomplete decomposing of organics are reasons for sulfur enrichment. Early discovery of euhedral and disseminated pyrite in Qingzhen convinces that pyrite formed both in sedimentary and diagenetic process.

\subsection{The Provenance Analysis}

In supergene conditions, new minerals produce from rock weathering, and a portion of the materials is dissolved into solution phase [10]. The high field strength elements $\mathrm{Zr}, \mathrm{Hf}$, $\mathrm{Nb}$ and Ta have relatively stable nature in weathering conditions, and hence are commonly used as tracers. $\mathrm{Zr} / \mathrm{Hf}$ and $\mathrm{Nb} / \mathrm{Ta}$ ratios are used to origin tracing, due to their similarity with host rock [11]. There is a linear relationship between the samples from Yunfeng bauxite and dolomite in Loushanguan Group in $\mathrm{Zr} / \mathrm{Hf}$ versus $\mathrm{Nb} / \mathrm{Ta}$ diagram. Hence, Loushanguan Formation is one source of bauxite in Qingzhen area.

\subsection{Metallogenic Environments}

Different sedimentary environment causes different dispersion and accumulation regularity of elements. Using trace element geochemical method can provide the basis for judging sea and continental sedimentary environment.The most widely used is the ratio of the element geochemical characteristics.

\subsubsection{The Paleoclimate}

$w(\mathrm{Mg}) / w(\mathrm{Ca})$ value is a good indicator for the paleoclimate change[12]. When we use $w(\mathrm{Mg}) / w(\mathrm{Ca})$ value to judge the paleoclimate, sylvite and sodium salt must be considered whether participate in precipitation. if participate in, the low $\mathrm{w}(\mathrm{Mg}) / \mathrm{w}(\mathrm{Ca})$ value and relatively high values of $\mathrm{K}^{+}, \mathrm{Na}^{+}$indicate a dry climate; if not, the high $(\mathrm{Mg}) / \mathrm{w}$ (Ca) value indicates a dry climate. the average content $\mathrm{K}_{2}$ Oand $\mathrm{Na}_{2} \mathrm{O}$ in the samples were $0.08 \sim 3.67 \mathrm{wt} \%$ and 0.04 $\sim 0.3 \mathrm{wt} \% \mathrm{~K}^{+}$and $\mathrm{Na}^{+}$content are low, it means they don't participate in precipitation, therefore, w $(\mathrm{Mg}) / \mathrm{w}(\mathrm{Ca})$ low value indicates a humid climate and high value indicators a dry climate. In this deposit, $w(\mathrm{MgO}) / w(\mathrm{CaO})$ is a low value.each partition average is from 0.47 to 1.35 , it shows that in the study area the early carboniferous epoch is relatively humid climate conditions.

\subsubsection{Oxidative-Reductive Conditions}

$\mathrm{Sr}$ and $\mathrm{Ba}$ have a wide distribution in the crust and $\mathrm{Sr} / \mathrm{Ba}$ value used to distinguish fresh water or salt water deposition. From freshwater sediment to salty deposition, $\mathrm{Sr} / \mathrm{Ba}$ value is increasing as far away from the ocean, $\mathrm{Sr} / \mathrm{Ba}$ value is lower in fresh water sedimentary than the sea [13]. $\mathrm{Sr} / \mathrm{Ba}$ ratio is $0.6 \sim 34.5$ in the bauxite, with an average of 12.38.it is higher than 13 modern seabed sediment samples in China, the ratio of $0.8 \sim 1.0$ [14], so we can deduce that bauxite is mainly formed in the Marine sedimentary environment.

$\mathrm{Ce}$ is an unstable layer structure, The $\mathrm{Ce}^{3+}$ has often been oxidized to $\mathrm{CeO}_{2}$ and separated from other trivalent rare earth elements. the stronger reducibility in sedimentary environment, the greater Ce loss. Ce anomaly can reflect the oxidation-reduction in sedimentary water. Elderfield [15] put forward the calculation formula of $\mathrm{Ce}$ anomaly: $\mathrm{Ce}_{\text {anom }}=\lg \left[3 \mathrm{Ce}_{\mathrm{A}} /\left(2 \mathrm{La}_{\mathrm{A}}+\mathrm{Nd}_{\mathrm{A}}\right)\right], \mathrm{A}$ is for standardization North American shale, When $\mathrm{Ce}_{\text {anom }}>-0.1$, characterized by enrichment of $\mathrm{Ce}$, it is anoxic condition; When $\mathrm{Ce}_{\text {anom }}<-0.1$, it shows the Ce losses, it is oxidation condition. Ceanom value in the deposit is greater than 0.1 ,it reflect the sediment deposition in the study area is in the lean oxygen - reduction environment.

For the samples of bauxite layer, $\mathrm{Th} / \mathrm{U}$ ratios is $1.52 \sim$ 3.92, an average of 2.86.According to Laukas [16]: $\mathrm{Th} / \mathrm{U}>$ 7 , bauxite is formation in intense laterization; $\mathrm{Th} / \mathrm{U}<2$, bauxite is formed in reducing environment. $\mathrm{Th} / \mathrm{U}$ is $2 \sim 7$, it is may an incomplete weathering or mixed sediments.so the provenance of mining bauxite can be both a reductive environment and an incomplete weathering or mixed sediments, mineralizing materials are of multi-sources.

Joens [17] think if $\mathrm{V} / \mathrm{Cr}>4.5 \mathrm{in}$ rocks, its sedimentary environment is anaerobic environment, and $\mathrm{V} / \mathrm{Cr}$ is $2.0-4.5$, it is poor oxygen, $\mathrm{V} / \mathrm{Cr}<2.0$, its sedimentary environment for oxygen-enriched environment. Ratio in the samples are between 2.0 to 4.5 , so it is belong to the reductive environment, lean oxygen.

\section{ORE-FORMING PROCESSES}

In combination with regional geological data,mineralogy, petrology and geochemistry characteristics of bauxite, we propose the Ore-forming processes of Yunfeng bauxite in Qinzheng, which can provide adequate theoretical prospecting exploration. it can be divided into three stages division :

In late Paleozoic Caledonian movement, the central Guizhou was uplift and then it had been denuded. In early carboniferous, central Guizhou old landhad formed a landform which widely distributed of karst depressions and catchment basin,having formed the favorable place for bauxite deposit [6].

At the end of the carboniferous stratum is exposed to the surface because of retrogression. the area is belonged to the hot and humid tropical climate, after intense weathering in tropical humid climate, $\mathrm{K}, \mathrm{Na}, \mathrm{Ca}, \mathrm{Mg}$ and other active elements were moved out while $\mathrm{Fe}, \mathrm{Al}, \mathrm{Ti}, \mathrm{Si}$ and other inactive 
elements were remained [18] On the flip side, in a tropical humid and hot climate, a large amount of plants decomposition can produce humic acid which is provided the favorable environment conditions for Si removal and Al enrichment. Part of the clay minerals form bauxite by desilication and a large number of alkali metals losed.

In the Carboniferous- Early Permian, Ore-bearing rock series was exposed to the surface several times and been weathering-leaching it make the $\mathrm{Si}$ and $\mathrm{Fe}$ loss further.the ore-forming parent material in the environment can further desilication and form bauxite. Guizhou area experienced the crust uplift at lateTriassic and had its conversion from sea to land after all the sea water regressed till Rhaetia. Thenthe later Tectonic movements uplift the "original bauxite"or clay bauxite to near-surface, so the coal beds or carbonaceous shale continued to produce the acidic and reducing groundwater to have secondary alteration and enrichment for the "original bauxite" or clay bauxite,which ultimately formed the high quality bauxite available to industrial exploitation [18].

In the ore-forming process, carbonate rock plays an important role, it has good permeability which can accelerate weathering and denudation, at the same time it provides channels for the elimination of impurities and offers accumulation place for bauxite affer been corrosion.

\section{CONCLUSION}

(1) The main mineral of Yunfeng bauxite are diaspore, kaolinite , chlorite and we can also find small amounts of boehmite, pyrite, zircon, anatase and rutile. Wall rock alteration did not occur, The study shows that diagenesis environment is mainly a reductive environment.

(2) The Major elements in bauxite ore are $\mathrm{Al}_{2} \mathrm{O}_{3}, \mathrm{SiO}_{2}(1.56 \% \sim 11.99 \%), \mathrm{Fe}_{2} \mathrm{O}_{3}, \mathrm{TiO}_{2}$ and the range of those elements distribution is wide. $\mathrm{Al}_{2} \mathrm{O}_{3}$ has a positively correlated with $\mathrm{TiO}_{2}$, but negatively correlated with $\mathrm{SiO}_{2}$ and $\mathrm{Fe}_{2} \mathrm{O}_{3}$. In the process of weathering,Ti elements remain stable but Si element lost. Al element has a certain loss, but concentration in total. rare earth element reveals a enrichment of LREE and HREE is relatively flat, it show a weak Ce anomaly

(3) $\mathrm{Zr}, \mathrm{Hf}, \mathrm{Nb}$ and other minor element have clearenrichment. $\mathrm{Zr}, \mathrm{Hf}, \mathrm{Nb}$, Ta and Ti have a positive correlation. $\mathrm{Zr} / \mathrm{Hf}$ and $\mathrm{Nb} / \mathrm{Ta}$ ratio show the source rock of Yunfeng bauxite may be the Loushanguan Formation dolomite.

(4) $\mathrm{K}^{+}$and $\mathrm{Na}^{+}$content are low in Yunfeng bauxite and it means they don't participate in precipitation, so the low value of $w(\mathrm{Mg}) / w(\mathrm{Ca})$ shows the early carboniferous epoch in the study area is a relatively humid climate conditions. $\mathrm{Ce}_{\text {anom }}>-0.1, \mathrm{Sr} / \mathrm{Ba}$ ratio is $0.6 \sim 34.5, \mathrm{~V} / \mathrm{Cr}$ is between 2.0 to 4.5 .it shows that the study area formed in the lean oxygen Marine sedimentary environment which is reductive environment. $\mathrm{Th} / \mathrm{U}$ is $2 \sim 7$, it is may an incomplete weathering or mixed sediments.so the provenance of mining bauxite can be both a reductive environment and an incomplete weathering or mixed sediments, mineralizing materials are of multi-sources.

(5) During the process of bauxite formation, Coal beds or other rock formation rich in organic material overlying the Al-bearing rock series produce acid reducing groundwater which may be important for bauxite mineralization.

\section{CONFLICT OF INTEREST}

The author confirms that this article content has no conflict of interest.

\section{ACKNOWLEDGEMENTS}

Declared none.

\section{REFERENCES}

[1] J. Zhang, "Situation and Countermeasures of China's Bauxite Resources", Value Engineering, vol. 21, pp. 4-5, 2012.

[2] P. Liu, "Discussion on the Metallogenic Setting of the QianzhongYu.nan Bauxite in Guizhou and Its Genesis", Guizhou Geology, vol. 18, no. 4, pp. 238-243, 2001.

[3] P. Liu, "An Additional Discussion on Bauxite deposits of Guizhou-Their Metallogenetic Epoeh,Material Source and Metallogenetie Mode”, Guizhou Geoology, vol. 10, no. 2, pp. 105-113, 1993.

[4] X. Liu, "Palaeokarst-Lateritic Origin Of Bauxite In Northern Guizhou”, Acta Geoological Sinica, vol. 64, no. 3, pp.238-247, 1990.

[5] 1. Chen, "Experimental study of action of humic acids in the processes of bauxite mineralization", Acta Sedimentologica Sinica, vol. 14, no. 2, pp.117-123, 1996.

[6] D. Gao, Z. Sheng, S. Shi, and L. Chen, "Studies on the Bauxite Deposit in Central Guizhou, China", Guiyang: Guizhou Science and Technology Publishing House, 11-20, 1992.

[7] H. W. Nesbitt, and G. M. Young, "Formation and diagenesis of weathering profiles", Journal of Geology, vol. 97, pp.129-147, 1989.

[8] Kennedy, "Phase relations in the system $\mathrm{Al}_{2} \mathrm{O}_{3}-\mathrm{H}_{2} \mathrm{O}$ at hightemperatures and pressures", American Journal of Science, vol.257, pp. 563-573, 1959

[9] S. Temur, and G. Kansun, "Geology and petrography of the Masatdagi diasporic bauxites, Alanya, Antalya, Turkey”, Journal of Asian Earth Sciences, vol. 27, no. 4, pp.512-522, 2006.

[10] H. W. Nesbitt, G. Markovics, and R. C. Price, "Chemical processes affecting alkalis and alkali earths duiring continental weathering", Geochimica Acta, vol.44, pp. 1659-1666, 1984

[11] I. Valeton, M. Biermann, R. Reche, and F. Rosenberg, "Genesis of nickel laterites and bauxites in Greece during the Jurassic and Cretaceous, and their relation to ultrabasic parent rocks", Ore Geology Reviews, vol.1, pp.359-404, 1987.

[12] S. Wang, X. Huang, J. Tuo, H. Shao, C. Yan, S. Wang, and Z. He, "Evolutional characteristics and their paleoclimate significance of trace elements in the Hetaoyuan formation , Bi yang depression", Acta Sedimentologica Sinica, vol.1, pp.65-70, 1991.

[13] L. Wang, and Q. Jia, "Trace element ratios used in geology", Petroleum geology, vol.11, pp.129-130, 2011.

[14] M. Hu, "Analyzing sedimentary environment using geochemical indicators-An example from north margin of Middle Yantze platform in Last Sinian", Petttroleum Exploration And Development, vol. 26, no. 6, pp.39-42, 1999.

[15] H. Elderfield, and M. Pagett, "REE in ichthyoliths: variations with redox conditions and depositional environment ", The Science of the Total Environment, vol.49, pp.175-197, 1986. 
[16] Laukas, "Rigin of Bauxite at Eufau la A labam", USA Clay Minerals, vol.18, pp.350-361, 1983

[17] B. Jones, and A. C. Manning, "Comparison of geochemical indicesused for the interpretation of palaeoredox conditions inancient mudstones ”, Chemical Geology, vol. 111, no. 2, pp.111-129, 1994.
[18] K. Ling, X. Zhu, Z. Wang, T. Han, H. Tang, and W. Chen, “ Metallogenic Model of Bauxite in Central Guizhou Province:an Example of Lindai Deposit", Acta Geologica Sinica, vol. 87, no. 6 pp. 1630-1642, 2013.

Received: July 16, 2015

Revised: August 23, 2015

Accepted: September 16, 2015

(C) Guoqing et al.; Licensee Bentham Open.

This is an open access article licensed under the terms of the Creative Commons Attribution Non-Commercial License (http://creativecommons.org/licenses/by$\mathrm{nc} / 3.0 /$ ) which permits unrestricted, non-commercial use, distribution and reproduction in any medium, provided the work is properly cited. 